\title{
SCJトピク
}

\section{インターアカデミー・パートナーシップが、 COVID-19に関して声明文を発表}

インターアカデミーパートナーシップ (InterAcademy Partnership; IAP) は、2020年3月27日に、 COVID-19に関して、2名の会長、5名の共同議長により合意された声明を発表しました。

インターアカデミーパートナーシップとは、140以上の国・地域の科学アカデミー等が加盟してい る国際学術団体で、日本学術会議も加盟しています。活動の目的は、自然科学、社会科学、工学及び 医学の科学者ネットワークをつなぎ合わせることにより、政策提言、科学教育の振興、保健衛生の向 上及びSDGsに代表される重要な開発計画を推進していくことです。

（声明文の内容につきましては、104頁以降をご参照ください。）

\section{Gサイエンス学術会議共同声明を公表}

G7サミットに向けた科学政策提言を目的としたGサイエンス学術会議では、共同声明を取りまと め、2020年5月 28 日に公表しました。共同声明のテーマは下記の通りです。

（1）基礎研究の重要性

（2）健康推進への情報技術の活用：デジタルヘルス・ラーニングヘルスシステム

（3）地球規模での昆虫減少による生態系サービスの消失

この他、（4）新型コロナウイルス感染症の世界的流行に係る国際協力の緊急的必要性について、を 2020年4月8日に先行して公表しました。

(共同声明の内容につきましては、2020年8月号に掲載する予定です。) 